\title{
DA EXPERIÊNCIA DO CINEMA NOVO AO NOVO CINEMA BRASILEIRO DO SÉCULO XXI: UMA ABORDAGEM SOCIOLÓGICA E POLÍTICA DO FILME BACURAU
}

\author{
From the experience of the New Cinema to the New Brazilian Cinema of the \\ 21 st century: a sociological and political approach of the Bacurau movie
}

José de Lima Soares ${ }^{101}$

\section{Resumo:}

O artigo se propõe a fazer uma análise do surgimento do Cinema Novo na contextualidade do quadro histórico-político marcado pelo populismo do final dos anos de 1950 e começo de 1960, passando pelo golpe civil-militar de 1964 e o desdobramento da ditadura militar que se prolongou por 21 anos. A ideia é demonstrar que o surgimento do Cinema Novo significou um avanço para além dos limites do cinema da época, mostrando a realidade social e política especialmente a partir de importantes nomes como Nelson Pereira dos Santos, Glauber Rocha, Joaquim Pedro de Andrade, Luiz Sérgio Person, Eduardo Coutinho, Roberto Santos, Ruy Guerra, Cacá Diegues, Leon Hirszhman, entre tantos outros. Dessa experiência surge uma nova linguagem que no cinema abre caminho para uma produção cinematográfica inovadora e uma interpretação crítica da realidade social e política brasileira. É um momento histórico que se caracteriza por um vasto painel que emerge como um verdadeiro caleidoscópio cultural e político, que inicia-se com o fim da ditadura estadonovista de Getúlio Vargas, passando pelo populismo com a política de Juscelino Kubitschek, Jânio Quadros e João Goulart, e chegando à derrocada das propostas populistas com o golpe civil-militar, que derrubou o governo de Jango. Na segunda parte, pretendo abordar o novo cinema emergente no século XXI no contexto histórico-político marcado pelo avanço da direita (e do bolsonarismo) a partir da obra de resistência de Kleber Mendonça Filho, envolvendo seu último filme, Bacurau, lançado em 2019, com ampla repercussão no Brasil e no mundo.

Palavras-chave: Cinema Novo; Glauber Rocha; Bacurau; Bolsonarismo.

\footnotetext{
${ }^{101}$ Doutor em Sociologia pela Universidade de Brasília (UnB). É professor associado de Sociologia e pesquisador do Instituto de História e Ciências Sociais (INHCS/UFCAT - GO). É pesquisador do CNPQ e do Grupo de Estudos e Pesquisas para o Trabalho (GEPT/UnB); é autor dos livros: Sindicalismo no ABC Paulista: Reestruturação Produtiva e Parceria e Outros Ensaios (Editora CRV, 2014), Ensaios de Sociologia do Trabalho (Editora Ciência Moderna, 2011), entre outros. E-mail: odijas@uol.com.br.
} 


\section{Abstract:}

The article proposes to make an analysis of the emergence of Cinema Novo in the context of the historical-political framework marked by the populism of the late 1950s and early 1960s, going through the 1964 civil-military coup and the unfolding of the military dictatorship that lasted for 21 years. The idea is to demonstrate that the emergence of Cinema Novo meant an advance beyond the limits of cinema at that time, showing the social and political reality especially from important names such as Nelson Pereira dos Santos, Glauber Rocha, Joaquim Pedro de Andrade, Luiz Sérgio Person, Eduardo Coutinho, Roberto Santos, Ruy Guerra, Cacá Diegues, Leon Hirszhman, among many others. From this experience, a new language emerges that in cinema paves the way for an innovative cinematographic production and a critical interpretation of Brazilian social and political reality. It is an historic moment that is characterized by a vast panel that emerges as a true cultural and political kaleidoscope, which begins with the end of Getúlio Vargas' dictatorship, passing through populism with the politics of Juscelino Kubitschek, Jânio Quadros and João Goulart , and reaching the collapse of populist proposals with the civil-military coup of March, which overthrew the Jango government. In the second part, I intend to approach the new emerging cinema in the 21st century in the historical-political context marked by the advance of the right wing (and Bolsonarism) based on the resistance work of Kleber Mendonça Filho, involving his last film, Bacurau, released in 2019, with wide repercussion in Brazil and in the world.

\section{Keywords: Cinema novo; Glauber Rocha; Bacurau; Bolsonarism}

\section{Introdução}

Muito já se falou e escreveu que o surgimento do Cinema Novo representou uma reação, por parte de jovens cineastas, a um cinema colonialista produzido no Brasil e muito bem expresso em produções como as da Companhia Vera Cruz. Na segunda metade da década de 50, vários movimentos ocorreram para que um cinema muito mais crítico se formasse no Brasil. Congressos que discutiram o cinema nacional, formação de grupos de estudos e comissões sobre o cinema brasileiro e principalmente a participação de cineastas vindos de meios críticos com a real situação do país, foram meios importantes na formação e consolidação desse novo cinema (JUNIOR, 2013).

Nelson Silva Júnior (2013) em sua pesquisa aponta que apesar de se chegar a um cinema propriamente brasileiro, o Cinema Novo não teve o êxito esperado pelos seus fundadores, junto ao grande público, que ainda preferia a forma holywoodiana clássica de se fazer cinema. O Cinema Novo funcionou à margem dos esquemas industriais de produção e distribuição. Tal fato se deu em grande medida por opção ideológica. Os diretores cinemanovistas não acreditavam que filmes concebidos segundo os paradigmas da indústria cultural tivessem a capacidade de levar às telas seus projetos revolucionários, tanto do ponto de vista político como estético, pois os dois projetos implicavam, entre outros aspectos, a experimentação de uma nova concepção de tempo e uma outra lógica para o pensamento, estranhas aos filmes de apelo comercial, voltados em sua maioria para a gratificação e o entretenimento (LEITE, 2005: 103).

Para Paulo Emílio Salles Gomes em sua obra Cinema: trajetória no subdesenvolvimento, "o Cinema Novo é, depois da Bela Época e da Chanchada, o terceiro acontecimento global de importância na história de nosso cinema" (GOMES, 1980: 94). O período compreendido entre 1907 e 1911, é conhecido como a "Bela Época do Cinema brasileiro", uma alusão à Belle Époque francesa, período compreendido entre o final do século XIX e o início da Primeira Grande Guerra, caracterizado pelas transformações culturais que a Europa passava. Nesse período, o cinema do Brasil se consolida pelo número de produções nacionais e também pela franca expansão de casas exibidoras. O cinema da Bela Época teve sua produção afetada pela pressão econômica do capital estrangeiro, enquanto o Cinema Novo sofreu as consequências de uma imposição política interna (GOMES, 1980). 
Indubitavelmente, o Cinema Novo propôs e criou uma nova estética visual e sonora num universo "integrado por sertão, favela, subúrbio, vilarejos do interior ou da praia, gafieira e estádio de futebol" (GOMES, 1980: 96), elementos constantemente presentes na filmografia nacional até os dias de hoje. O Cinema Novo trouxe em sua essência a proposta de um cinema político do chamado Terceiro Mundo ${ }^{102}$, no qual se percebia o diálogo sobre as questões coletivas que permeavam temas como: as lutas de classe, a religião, a política, o anticolonialismo, a libertação do oprimido (JUNIOR, 2013).

Para Jean-Claude Bernardet (2006) o Cinema Novo criou uma situação cultural nova: apesar da repercussão de Rio, Quarenta Graus e mais um ou outro filme, o cinema brasileiro era totalmente desconsiderado pelas elites culturais; só o público popular se relacionava bem com uma parte da produção, geralmente conhecida como "chanchada". Com o Cinema Novo, as elites - ou parte delas - passam a encontrar no cinema uma força cultural que exprime suas inquietações políticas, estéticas, antropológicas. Externamente, o Cinema Novo permitiu que se estabelecesse com outros países um diálogo cultural; é raro que isto ocorra por parte de um país subdesenvolvido. Esse trabalho internacional do Cinema Novo foi importante para sua receptividade interna. A elite, por ser dependente dos centros culturais dos países industrializados, hesitava em aceitar o Cinema Novo. A repercussão internacional dos filmes deu-lhe uma certa segurança. Se a Europa elogiava, é que algo de elogiável devia haver (BERNARDET, 2006).

O Cinema Novo surge como uma voz revolucionária em meio a uma tensa situação política, seis meses após o golpe de Estado que depôs, em 1964, o governo de João Goulart e em uma época em que a produção cinematográfica era objeto de consumo condicionado ao colonialismo. Tudo começa em 1952 com o I Congresso Paulista de Cinema Brasileiro e o I Congresso Nacional do Cinema Brasileiro. Por meio desses congressos, foram discutidas novas ideias para a produção de filmes nacionais. Uma nova temática de obras já começa a ser abordada e concluída mais adiante, por uma nova fase do cinema que se concretiza na década de 1950 (COSTA, MOTTA, RICCO; [200-?]) ${ }^{103}$.

De acordo com Silva Junior (2006) no Cinema Novo, portanto, convergiam duas grandes tendências: a arte e a política. Neste contexto Glauber Rocha se configurou no cinemanovista que melhor representou o movimento, pois além de ser o diretor brasileiro mais conhecido no exterior, ele é o único a se comprometer a levar a diante o ideário cinemanovista, mesmo no período dos anos 70, quando o movimento apresentava sinais de falência. Reconhecidamente, nenhum outro se empenhou de modo tão intenso na continuidade do Cinema Novo ${ }^{104}$.

Silva Junior (2006) entende ainda o Cinema Novo não apenas um movimento artístico/cultural, mas como expressão real da militância de um grupo de intelectuais interessados em atuar politicamente. Nesse sentido a câmera se torna um instrumento que serve para perscrutar a realidade social e para propor

\footnotetext{
${ }^{102}$ A noção de Terceiro Mundo foi muito utilizada pelos cinemanovistas, bem como por muitos intelectuais, cientistas políticos e sociólogos de esquerda, vinculados aos projetos nacionalistas e desenvolvimentistas implementados por governos populistas latino-americanos, nos anos 1950/1960. Com exceção de alguns teóricos da teoria da dependência, como Ruy Mauro Marini, Vania Bambirra e Theotonio dos Santos, que partiam da premissa de que esses países, incluindo o Brasil, poderiam ser qualificados como periféricos e dependentes em relação aos países centrais. Com a queda do muro de Berlim, o desmoronamento do chamado socialismo real e o intenso processo de globalização e mundialização do mundo capitalista, o termo Terceiro Mundo praticamente caiu em desuso. Os teóricos da dependência assinalavam que o desenvolvimento do capitalismo havia estabelecido uma divisão internacional do trabalho hierarquizada. Nesta hierarquia, as contradições entre as classes dominantes dos países dependentes e os monopólios internacionais não os levavam à confrontação, pois, as primeiras buscavam o capitalismo internacional. O subdesenvolvimento correspondia a esta posição subordinada dentro da economia mundial. Por exemplo, logo na introdução do célebre texto Dialética da Dependência, Marini ressalta a diferença de trajetória de desenvolvimento das economias dependentes em relação ao capitalismo avançado. A tese de Marini se inscreve e aproxima-se da lógica do desenvolvimento desigual, combinado e contraditório defendida por outros autores, como Leon Trotsky, em História da Revolução Russa, e Octavio lanni, em A sociedade Global.
} 
soluções, e que em última instância tinha como meta estimular um processo revolucionário. Esses motivos são suficientes para apontar Glauber Rocha como o principal personagem da história do Cinema Novo, mas um outro motivo também o coloca nessa posição: a sua filmografia. Glauber mantém as características cinemanovistas como, entre outras: a improvisação, a fragmentação nas imagens, a referência revolucionária, a violência, a religião, os diálogos gritados, a temática sobre o Brasil e o posicionamento político de esquerda, de denúncia da miséria provocada pelo colonialismo antigo e moderno. Esses elementos acompanham quase todos os seus filmes, de Barravento (1961), A Idade da Terra (1980), O Leão de Sete Cabeças (1970) ${ }^{105}$ uma fidelidade não encontrada em outros cineastas do grupo. Pelo contrário, alguns deles como Nelson Pereira dos Santos e Carlos Diegues negam, já na primeira metade dos anos 1970, a continuidade do Cinema Novo.

Na concepção de Leite (2005), em país marcado por profundas desigualdades sociais, o cinema poderia ser a janela para um olhar muito mais crítico de uma população que vivia sob um ilusionismo hollywoodiano.

O cinema brasileiro deu uma resposta crítica a este processo peculiar, engajando-se politicamente e alinhando-se ao espírito radical dos anos 1960. Ao mesmo tempo, como parte de sua agenda política, o Cinema Novo tentou problematizar sua inserção na esfera da indústria cultural, apresentando-se no mercado, mas procurando ser sua negação e seu questionamento, procurando com tal perspectiva sua inserção na tradição cultural erudita (LEITE, 2005: 96).

Essa nova fase pôde ser bem refletida a partir do filme Rio, 40 Graus (1955), de Nelson Pereira dos Santos. As propostas do neorrealismo italiano que Alex Viany ${ }^{106}$ vinha divulgando, foram a inspiração do autor do filme. A importância desse filme é salientada por Raquel Gerber (1977: 13) quando diz que:

[...] ele inauguraria a possibilidade de um "cinema independente" no Brasil contra os preceitos da "grande produção industrial". A proibição do filme, que gera uma repercussão de caráter nacional, marca politicamente as origens do cinema novo. Glauber Rocha dirá que "Rio, 40 graus" é um documento de importância antropológica - como único filme sobre o Brasil na realidade dos anos 50 .

${ }^{103}$ Cf. COSTA, Nicoly de Souza; MOTTA, Rafael Vieira; RICCO, Adriana Sartório. A linguagem do cinema novo: Glauber Rocha e seus mitos. Disponível em < http://webjornal.fesv.br/artigos/arquivos/alunos/rafael.pdf>

${ }^{104}$ Considerado por Ismail Xavier como a primeira experiência brasileira de cineastas pertencentes à mesma geração, o Cinema Novo era formado por jovens intelectuais e artistas cujo "acontecimento fundador" - marca geracional que thes confere unidade, na acepção de Jean-François Sirinelli (1996) - seria o golpe de Estado que instaurou a ditadura civil-militar no país em março de 1964. Glauber Rocha, Joaquim Pedro de Andrade, Cacá Diegues, Ruy Guerra, Paulo César Saraceni, Leon Hirszman, Gustavo Dahl, Domingos de Oliveira, entre outros, pertenceriam, portanto, à geração de 1964. A exceção fica por conta de Nelson P. dos Santos, um pouco mais velho, mas totalmente identificado com os projetos da nova geração, que the tomou como paradigma.

${ }^{105}$ Produção italiana, realizada no Congo, África, em 1970, O Leão de Sete Cabeças é, segundo seu diretor, "um ato político-cultural de colaboração com a noção de luta tricontinental (Conferência organizada pelo povo cubano, envolvendo movimentos revolucionários da África, Ásia e América Latina)", teorizada pelo guerrilheiro argentino Ernesto Che Guevara. Considerado aqui como aplicação do manifesto Tricontinental, o filme tornou-se um importante documento histórico, cuja análise pode revelar não só os símbolos culturais e alegorias políticas que se articulam no cinema antropológico de Glauber Rocha, como também, as visões ideológicas dos atores sociais envolvidos em questões de dependência e resistência colonialista e neocolonialista nos países dependentes e periféricos. Engajado no exercício de uma prática cinematográfica que objetiva denunciar os males da opressão, Glauber Rocha adquiriu prestígio internacional com uma produção marcada por dimensões políticas. Analisar os atributos políticos e estéticos presentes em $\mathrm{O}$ leão de Sete Cabeças, filmado no Congo, em 1969, é a proposta deste trabalho. No filme, ao discutir a questão colonialista na África, o cineasta criticou a espoliação decorrente dos séculos de colonização e estabeleceu o elogio das lutas de libertação nacional no continente. Ademais, o artista questionou as noções de "civilizado" e "bárbaro" ao pôr em ação a ideia de realizar um cinema voltado ao "Terceiro Mundo", conforme a noção adotada à época. 
Raquel Gerber (1977) entende que os filmes seriam voltados à realidade brasileira e com uma linguagem adequada à situação social da época. Os temas mais abordados estariam fortemente ligados ao subdesenvolvimento do país. Esse tipo de cinema destinava-se a ser um instrumento de conscientização, “[...] produtos ideológicos que tivessem consequências ideológicas” (GERBER, 1977: 17).

Outra característica dos filmes durante o cinema novo é que eles tinham imagens com poucos movimentos, cenários simplórios e falas mais longas do que o habitual. Muitos ainda eram rodados em preto e branco.

Para alguns pesquisadores como Costa, Motta e Ricco [200-?], o cinema novo foi composto por três importantes fases. A primeira delas vai de 1960 a 1964. Nesse período, os filmes eram voltados ao cotidiano e à mitologia do nordeste brasileiro, com os trabalhadores rurais e as misérias da região. Eram abordados também a marginalização econômica, a fome, a violência, a opressão e a alienação religiosa. Algumas das produções que melhor expressam essa fase são os filmes Vidas Secas (1963), de Nelson Pereira dos Santos; Os Fuzis (1963), de Ruy Guerra; e Deus e o Diabo na Terra do Sol (1964), de Glauber Rocha (COSTA; MOTTA; RICCO, [200-?].

A segunda fase do cinema brasileiro agora tem um novo propósito. Os cineastas analisavam os equívocos da política desenvolvimentista e principalmente da ditadura militar. Os filmes também faziam reflexão sobre os novos rumos da história nacional. Nessa fase, que vai de 1964 a 1968, as obras características são: O Desafio (1965), de Paulo Cezar Saraceni, O Bravo Guerreiro (1968), de Gustavo Dahl e Terra em Transe (1967), de Glauber Rocha. O filme de Glauber Rocha constitui uma reflexão sobre a ideia de populismo, tanto no plano político quanto cinematográfico. A terceira e última fase do Cinema Novo, que vai de 1968 a 1972 é, neste momento, influenciada pelo tropicalismo. O movimento levava suas atitudes às últimas consequências e extravasou por meio do exotismo brasileiro (COSTA, MOTTA, RICCO; [200-?].

De acordo com Costa, Mota e Ricco [200-?] o filme Deus e o Diabo na Terra do Sol produzido em 1963, conta a saga de um vaqueiro, Manuel, que se revolta contra a exploração de que é vítima por parte do coronel Morais e mata-o durante uma briga. Foge com a esposa Rosa da perseguição dos jagunços e acaba se integrando aos seguidores do Beato Sebastião, no lugar sagrado de Monte Santo, que promete a prosperidade e o fim dos sofrimentos através do retorno a um catolicismo místico e ritual. Ao presenciar o sacrifício de uma criança, Rosa mata o beato. Ao mesmo tempo, o matador de aluguel Antônio das Mortes, a serviço dos coronéis latifundiários e da Igreja Católica, extermina os seguidores do beato. Em nova fuga, Manoel e Rosa se juntam a Corisco, o diabo loiro, companheiro de Lampião que sobreviveu ao massacre do bando. Antônio das Mortes persegue de forma implacável e termina por matar e degolar Corisco, seguindo-se nova fuga de Manoel e Rosa, desta vez em direção ao mar. O filme conta algo de muito moderno: as alucinações, as visões, as práticas e os modos de conduta aberrantes que a fome, a miséria e a ignorância podem inspirar num povo desesperado (COSTA, MOTTA, RICCO, [200-?].

O Santo Sebastião e Corisco representam Deus e o diabo, ambos deformados e transtornados pela solidão do sertão. A solução do problema social representado por figuras como o Santo Sebastião e Corisco é confiada a Antônio das Mortes, matador profissional, figura sinistra, melancólica e lógica de assassino visionário, o qual imagina que, uma vez eliminados o diabo (Corisco) e Deus (Santo Sebastião), haverá en-

\footnotetext{
${ }^{106}$ Aliás, Almiro Viviani Fialho, que como Glauber, insistiam que a propedêutica do diretor de cinema Humberto Mauro revelava os indícios que deveriam ser perseguidos pelo Cinema Novo: o filme como expressão do homem; o filme que nasce como pensamento contra o extermínio de ideias propiciado pelo cinema industrial; o filme barato e artesanal; o filme não-submetido às regras narrativas da prática comercial; o filme de montagem livre, seguindo um tempo movido por um ritmo interior; o filme de autoria, que levaria à compreensão dos valores objetivos da paisagem física e social. Inegavelmente, o neorrealismo italiano, a partir de diretores como Vittorio De Sica (Ladrões de Bicicletas ), Roberto Rosselini (Roma, Cidade Aberta), Luchino Visconti (Rocco e Seus Irmãos) exerceu grande influência sobre os cinemanovistas. Ver: FABRIS, Maria rosaria; SANTOS Nelson Pereira. 1994. Um olhar neorrealista? São Paulo: Edusp.
} 
tão a revolução que redimirá o sertão. Assim, Antônio das Mortes fulmina o profeta e o bandido. Manuel, símbolo do povo brasileiro, escapa, testemunha viva da verdade das teses do filme.

Terra em Transe, produzido em 1966, é um grande clássico do Cinema Novo, faz duras críticas à ditadura. Tem como temas centrais o populismo, as utopias libertárias de esquerda e o concerto barroco de diversas culturas (africana, índia, branca). “Transe” é a instabilidade das consciências, um momento de crise.

Num país fictício chamado Eldorado, o jornalista e poeta intelectual burguês Paulo, oscila entre diversas forças políticas, envolvendo militares, militantes, intelectuais, políticos e empresários, todos em luta pelo poder. Paulo Martins é a consciência em transe de Eldorado. Ele, poeta e soldado, se dilacera na tentativa de abraçar as contradições de Eldorado para forjar o instrumento de luta capaz de redimir o país.

Uma Estética da Fome - o mais importante e influente manifesto do cinema brasileiro - veio a público em julho de 1965. O cineasta baiano Glauber Rocha, diretor de Deus e o Diabo na Terra do Sol (1964), apresentou o documento durante o congresso Terceiro Mundo e Comunidade Mundial, na cidade italiana de Gênova. De imediato, por sistematizar o ideário e as diretrizes do Cinema Novo, o manifesto se tornou uma espécie de estatuto do movimento. Segundo Glauber, "somente uma cultura da fome, minando suas próprias estruturas, pode superar-se qualitativamente: e a mais nobre manifestação cultural da fome é a violência” (GLAUBER,1965: 165).

Para Castelo (2010) os cinemanovistas produziram narrativas audiovisuais sobre a teoria e a ação revolucionárias, em concomitância com as narrativas escritas no seio da militância e da intelectualidade, consagrando-se, assim, como alguns dos principais formuladores de uma concepção do caráter da revolução brasileira $^{107}$. Com base nessa premissa, analisa-se como o filme Terra em transe (1967) problematiza o ideário revolucionário hegemônico em três contextos distintos, separados pelo golpe civil-militar de 1964 e o AI-5: o primeiro marcado pela defesa de uma "revolução democrático-burguesa de conteúdo antifeudal e anti-imperialista”, levada a efeito pela aliança entre burguesia nacional, PCB (conhecido na literatura de esquerda como o "Partidão"), operários e camponeses contra os latifundiários e as multinacionais, inspirada nos postulados da III Internacional ${ }^{108}$ sob a direção do estalinismo e que, com base na teoria do "socialismo em um só país" defendia a revolução por etapas, difundidos no Brasil pelo PCB; o segundo celebrado pela relativa superação

\footnotetext{
107 Foram muitos os que procuraram teorizar sobre o caráter da revolução brasileira. Grosso modo, a questão era se a revolução brasileira seria de caráter burguês ou socialista, ou seja, se seria necessário superar os resquícios feudais para, e aí realizar a transição democrático-burguesa para, em seguida, avançar em direção ao socialismo. Desde a fundação do PCB, em 1922, com Astrojildo Pereira, Octávio Brandão, passando pelos dissidentes trotskistas, como Mario Pedrosa, Lívio Xavier, Hermínio Sacchetta, nos anos de 1930/40, seguido por Érico Sachs (Ernesto Martins) do grupo Política Operária (POLOP), Ruy Mauro Marini, Caio Prado Jr., João Amazonas (PC do B), bem como os representantes da guerrilha urbana e rural, como Carlos Marighella, dentre outros. O livro A revolução brasileira, de Caio Prado Jr., lançado em 1966, influenciou fortemente grande parte da esquerda. A revolução burguesa no Brasil, de Florestan Fernandes, também teve grande repercussão e influência no pensamento crítico de esquerda. O mesmo ocorre com a Dialética da dependência e Subdesenvolvimento e Revolução e na América Latina, de Ruy Mauro Marini. Esse conjunto de concepções políticas e ideológicas acabaram influenciando, de alguma maneira, o Cinema Novo. Exemplo disso é o próprio Nelson Pereira dos Santos, Leon Hirszhman, que eram membros do PCB. É uma questão complexa, não resolvida, e que continua sendo a tônica do debate no campo da esquerda, até mesmo nos dias atuais.
}

108 III Internacional é a abreviação de Internacional Comunista (Comintern), reunião internacional dos Partidos Comunistas de diversos países, que funcionou de 1919 até 1943. A Internacional Comunista foi sucessora e continuadora da Primeira Internacional e herdeira das melhores tradições da Segunda Internacional. A fundação da Internacional Comunista significou a criação de um Estado Maior político-ideológico do movimento revolucionário do proletariado. Lênin foi o organizador e inspirador da Internacional Comunista, que defendeu o marxismo revolucionário frente às deformações oportunistas e revisionistas de direita e de "esquerda". A Internacional Comunista buscou a formação de quadros dirigentes dos Partidos Comunistas e a sua transformação em partidos revolucionários de massa, partidos de novo tipo. A Internacional Comunista degenerou após a ascensão de Stalin em 1922 e foi dissolvida em 1943 como um gesto de conciliação de Stalin para com a Forças Aliadas (Estados Unidos, Inglaterra). Ver Tom Bottomore, Dicionário do pensamento marxista. Rio de Janeiro: Jorge Zahar, 1983. 
do etapismo revolucionário e a ação armada de grupos guerrilheiros influenciados pelo foquismo cubano ${ }^{109}$, através da perspectiva guerrilheira e o maoísmo pela chamada "guerra popular prolongada" (o campo cercando a cidade), tomando como base a guerrilha rural, como se verá na guerrilha do Araguaia; o terceiro fundado na práxis revolucionária de pequenos grupos revolucionários influenciados pela teoria da dependência de Ruy Mauro Marini, Teotônio dos Santos, Vânia Bambirra, Andre Gunder Frank e alguns militantes trotskistas que recusavam ambas alternativas e seguiam defendendo a construção de um partido revolucionário e a organização autônoma dos trabalhadores a partir da intervenção nos organismos de massas, como os sindicatos, movimentos sociais etc; e o quarto que partia da ideia de uma modernização conservadora engendrada pelos militares, sob as diretrizes da doutrina de segurança nacional, com ressonâncias sebastianistas (qualquer movimento com característica messiânica) e contrarreformistas. Igualmente, crê-se que, transpondo os fundamentos e estratégias revolucionárias no contexto brasileiro, a película de Glauber Rocha enseja a problematização da própria mentalidade revolucionária, entendida por Leszek Kolakowski como a crença na redenção integral do homem, mediante a negação absoluta do mundo existente, no fim do qual se subordinariam todos os outros valores, transmutados, por conseguinte, em meios (CASTELO, 2010) ${ }^{110}$.

No caso de Terra em Transe, a narrativa do filme parte da esperança frustrada de que o Governador da Província de Alecrim e líder político Dom Felipe Vieira, político populista, seria uma alternativa política ao conservador Dom Porfírio Diaz, líder de direita, político paternalista da capital litorânea de Eldorado, ditador fascista que apela ao misticismo para preservar o poder. Entre estes, se interpõe a figura do capitalista Júlio Fuentes, a expressão máxima da burguesia progressista de Eldorado, que apesar de se declarar de esquerda acaba se aliando ao ditador Diaz. Em uma conversa com a militante Sara, uma intelectual comunista, Paulo conclui que não há outra solução a não ser a violência revolucionária suicida e que o povo precisava de um líder e, Vieira tem os pré-requisitos para a missão.

Essa tarefa é descrita por René Gardies (1977) como uma guerra de uma expressão alienada para chegar até a consciência de si mesma, guerra de um modo de expressão - o cinema - submetido a uma intensa aculturação a fim de se enraizar na palavra nacional, finalmente, guerra que trava na frente cultural num combate precursor de uma outra revolução.

\footnotetext{
${ }^{109}$ Teoria revolucionária inspirada em Ernesto Guevara e desenvolvida pelo filósofo francês, Regis Debray, em seu livro Revolução na revolução, publicado em 1967, e que foi muito utilizado pelos grupos revolucionários de guerrilheiros que aderiram à luta armada no Brasil e na América Latina. Com essa teoria, acreditavam e defendiam criar focos revolucionários de resistência em todo mundo, como forma de enfraquecer o imperialismo e sintetizada na Mensagem à Tricontinental, em março de 1967, por Ernesto Guevara: “Criar um, dois, três, muitos Vietnãs".

${ }^{110} \mathrm{Na}$ verdade, trata-se de duas teorias da dependência: uma encabeçada por Fernando Henrique Cardoso e Enzo Faletto, de cunho weberiano, e outra liderada por Ruy Mario Marini vinculada à concepção marxista. Rejeitando qualquer tipo de confrontação, Cardoso propunha como modelo econômico e político para a América Latina, a dependência negociada. Porque a tentativa de alcançar autonomia nacional pelos movimentos populares e suas lideranças, construída ideologicamente pelo nacional-desenvolvimentismo, deflagrou nestes países os golpes militares de Estado dos anos 1960 e 1970. Utilizando os conceitos marxistas, de forma rigorosa e criativa, Marini lança luz sobre outros aspectos que explicam as razões pelas quais as classes dominantes dos países dependentes optam pela situação de subordinação dentro da economia mundial. Não foi somente através da associação negociada com o capital estrangeiro que as burguesias dos países dependentes conseguiram a acumulação de excedentes, elas utilizaram-se do recurso da maior exploração do trabalhador para alcançar o processo de acumulação capitalista para compensar suas debilidades no mercado internacional. Segundo Marini, a superexploração do trabalho é caracterizada por três processos que poderiam atuar de forma conjugada ou isolada: o aumento da jornada de trabalho, a maior intensidade do trabalho e a redução do fundo de consumo do trabalhador. Para uma análise mais profunda, ver: CARDOSO, F. H. e FALETTO, Enzo. Dependência e desenvolvimento na América Latina: ensaio de interpretação sociológica. Rio de Janeiro: Zahar, 1977. MARINI, Ruy Mauro. Subdesenvolvimento e Revolução. Florianópolis: Insular, 2012. MARINI, R. M. TRASPADINI, Roberta; STÉDILE, João Pedro (Orgs). Ruy Mauro Marini Vida e Obra. São Paulo: Expressão Popular, 2005.
} 
De acordo com Gardies (1977), não há quem se equipare a Glauber. O cinema, a poesia, a revolução no sentido de um homem latino-americano falando de suas dores, numa estética própria, verdadeira. Glauber conseguiu aliar discurso numa estética própria em uma época em que fazer cinema era caro demais. Hoje ainda continua caro, mas nós temos uma tecnologia que, quem sabe, estava nos sonhos daqueles jovens que fizeram a história de nosso cinema (GARDIES, 1977)

O movimento pretendia, primeiramente, libertar o cinema dos laços coloniais e da produção estrangeira. Usando elementos da cultura popular nacional, criticou a alienação cultural e política da sociedade de forma a gerar uma reflexão e quem sabe ações contra esta cultura de alienações. Nesse sentido, a contribuição de Glauber é muito maior que um escrito estético. Proporcionou-nos discorrer sobre suas obras dando a possibilidade para que novos talentos da produção cinematográfica compreendam sua intenção ao construir roteiros de caráter tão ricamente crítico quanto à dele.

Após um período de produções ditas industriais, como o caso da Vera Cruz e suas grandes produções inspiradas em obras "hollywoodianas", tem-se, no Brasil, o esforço por parte de um grupo de cineastas para revolucionar o modo que até então se fazia cinema no país. Produções de baixo custo, de contato direto com a realidade da população e que buscavam temas nacionais, essas eram as principais características do Cinema Novo. De acordo com Jean-Claude Bernardet, os filmes "cinemanovistas" procuravam "dar uma visão abrangente dos problemas básicos da sociedade brasileira e, pode-se acrescentar, do Terceiro Mundo em geral. Esse esforço intencional para alcançar uma compreensão global do social subdesenvolvido era algo totalmente novo no cinema brasileiro" (BERNARDET, 2004:103).

Intencionalmente também, essas produções deviam levar a um público popular informações que o conscientizasse de sua situação social, conforme afirma Glauber Rocha:

O que fez do Cinema Novo um fenômeno de importância internacional foi justamente seu alto nível de compromisso com a verdade; foi seu próprio miserabilismo, que, antes escrito pela literatura de 30, foi agora fotografado pelo cinema de 60; e, se antes era escrito como denúncia social, hoje passou a ser discutido como problema político (ROCHA, 1965: 167).

Os cineastas deste movimento procuravam, neste sentido, desenvolver um cinema preocupado com os problemas nacionais, expondo através de seus filmes todas as mazelas da população. "O Cinema Novo é um projeto que se realiza na política da fome, e sofre, por isto mesmo, todas as fraquezas consequentes da sua existência" (ROCHA, 1965: 170) ${ }^{112}$.

O cinema para Glauber Rocha era muito mais do que apenas um campo artístico, era um espaço de atuação. O cineasta, um dos mais importantes agitadores culturais de sua época, preocupou-se não

\footnotetext{
${ }^{111}$ Aqui, à guisa de exemplo, procuro resgatar a concepção benjaminiana de cinema. Benjamin (1985) com sua compreensão dos meios de comunicação de massas, aborda a partir da discussão sobre a "reprodutibilidade técnica" uma questão cara ao marxismo revolucionário - e que parece estar presente na obra glauberiana: "Quando Marx empreendeu a análise do modo de produção capitalista, esse modo de produção ainda estava em seus primórdios. Marx orientou suas investigações de forma a dar-Ihes valor de prognósticos. Remontou às relações fundamentais da produção capitalista e, ao descrevê-las, previu o futuro do capitalismo. Concluiu que se podia esperar desse sistema não somente uma exploração crescente do proletariado, mas também, em última análise, a criação de condições para sua própria supressão" (BENJAMIN, 1985: 165).

${ }^{112}$ Glauber Rocha se remonta a questão da fome conforme a interpretação do médico e sociólogo Josué de Castro que em seu clássico Geopolítica da fome apontava para o fenômeno da fome, ao afirmar que: "a fome leva mais longe seus efeitos destruidores (...) levando-os à apatia e ao conformismo ou à explosão desordenada de rebeldias improdutivas, verdadeiras crises de nervos de populações neurastênicas e avitaminadas. Glauber entendia a reivindicação de um cinema da fome para se opor aos cinemas dos países bem nutridos, e como ele conseguiu expressar isso magistralmente" (GARDIES, 1977: 94).
} 
somente com a arte, mas, sobretudo, em como suas obras poderiam servir de instrumento para sua luta política. Glauber Rocha acreditava no Brasil e em sua potencialidade. Sua obra reflete seus anseios e seu esforço para que a população não afirmasse sua alienação frente à situação social nacional. Enquanto intelectual produziu inúmeros textos, artigos e entrevistas, e como artista concebeu uma série de filmes e peças de teatro com o intuito de transmitir conhecimento e crítica política ao maior número possível de brasileiros. O cinema, através das produções influenciadas por este pensamento, se afina com a política ao tornar-se um agente motivador de mudanças estruturais da sociedade.

Deve-se ir além da descrição e da análise da realidade, a fim de levar o público a atuar; a situação não mudará se ele não agir para transformá-la e só ele pode ser o motor dessa transformação. Trata-se de politizar o público (BERNARDET, 2007: 41).

Essa marca estaria presente nos filmes precursores do Cinema Novo - de Aruanda (Linduarte Noronha, 1959) a Vidas Secas (Nelson Pereira dos Santos, 1963). Conforme o manifesto A estética da forme, lançado por Glauber, em 1965:

uma estética da violência antes de ser primitiva é revolucionária, eis aí o ponto inicial para que o colonizador compreenda a existência do colonizado; somente conscientizando sua possibilidade única, a violência, o colonizador pode compreender, pelo horror, a força da cultura que ele explora. Enquanto não ergue as armas, o colonizado é um escravo (...) A América Latina, inegavelmente, permanece colônia, e o que diferencia o colonialismo de ontem do atual é apenas a forma aprimorada do colonizador: e, além dos colonizadores de fato, as formas sutis daqueles que também sobre nós armam futuros botes. O problema internacional da América Latina é ainda um pouco de mudança de colonizadores, sendo que uma libertação possível estará sempre em função de uma nova dependência (ROCHA, 1965: 166-169).

Glauber encarnou o espírito do Cinema Novo descrito anteriormente e na sua reação ao ocupante (colonizador) definido por Paulo Emílio Salles Gomes, ao afirmar que o cineasta colocou a teoria de Fanon como uma das matrizes de sua proposta cinematográfica; a análise agudamente crítica de Fanon sobre o colonialismo é base do principal manifesto do Cinema Novo (Estética da Fome), para analisar o "novo colonialismo", concepção elaborada por parte principalmente de setores da esquerda ${ }^{113}$.

Humberto Alves Silva Junior (2017) entende que em Frantz Fanon há um fato fundante dos problemas sociais que é o econômico. O racismo estaria entrelaçado com a esfera econômica, por conseguinte a luta antirracial não estaria dissociada da luta de classes. Por essa ótica, observa-se que a teoria de Fanon constata que a liberdade humana necessariamente passaria pelo fim das classes, e o fim de uma sociedade racista dependeria da superação da sociedade de classe. O que transparece que a verdadeira desalienação do negro implica uma tomada abrupta de consciência das realidades econômicas e sociais. Fanon (1977; 2008) também reafirma que não defende a superioridade de nenhuma etnia e aponta a solidariedade como princípio importante da relação entre os homens. ${ }^{114}$

\footnotetext{
${ }^{113}$ A propósito desta questão, ver Albert Memmi, Retrato do colonizado precedido pelo retrato do colonizador. Rio de Janeiro: Paz e Terra, 1977. De acordo com Antonio Sérgio Guimarães (2008), Glauber toma conhecimento da obra de Fanon (Os condenados da terra) em 1968, mas é possível que já tivesse lido o prefácio de Jean Paul Sartre.

114 Questão debatida e retomada por Aníbal Quijano, Colonialidade do poder, eurocentrismo e América Latina. LANDER, Edgardo (org). A colonialidade do saber: eurocentrismo e ciências sociais. Buenos Aires: Conselho Latino-americano de Ciências Sociais - CLACSO, 2005. p. 227-229.
} 
O cineasta Glauber Rocha explicita sua inspiração em Fanon no manifesto Estética da Fome ao relacionar os termos "do Cinema Novo" e "da violência", esta última expressão começa o primeiro capítulo do livro de Fanon, Os Condenados da Terra de (1961). Glauber faz uma analogia ao termo fanoniano "da violência":

(...) Do Cinema Novo: uma estética da violência antes de ser primitivo (é) revolucionário, eis aí o ponto inicial para que o colonizador compreenda a existência do colonizado: somente conscientizando sua possibilidade única, a violência, o colonizador pode compreender, pelo horror, a força da cultura que ele explora. Enquanto não ergue as armas o colonizado é um escravo: foi preciso um primeiro policial morto para que o francês percebesse um argelino (ROCHA, 1980: 31-32).

Silva Junior (2017) parte da concepção de que o manifesto Glauber se refere diretamente a violência que se coloca como forma de autodefesa, pois somente é reconhecido pelo outro (colonizador) a partir de uma atitude extrema, o ato de matar, somente deste modo o ser colonizado emerge e tem sua identidade afirmada. Em Fanon o aspecto da exploração que sobressai é o tema da violência física e sobretudo psíquica que sustentam a condição colonial. Para Glauber parte dessa violência é a própria fome, ao reagir à violên$\mathrm{cia}^{115}$ do ocupante (colonizador), existe uma reação de ódio, segundo Fanon; mas de um ódio específico para Glauber, como afirma na Estética da Fome:

De uma moral: essa violência, contudo, não está incorporada ao ódio, como diríamos não está ligada ao velho humanismo colonizador. $\mathrm{O}$ amor que essa violência encerra é tão brutal quanto à própria violência, porque não é um amor de complacência ou de contemplação, mas um amor de ação e transformação (ROCHA, 1980: 30-31).

No fundo, os cinemanovistas - mas fundamentalmente Glauber apontavam questões fundantes colocadas por importantes intérpretes do Brasil como Florestan Fernandes em seus livros A revolução burguesa no Brasil, Capitalismo Dependente e classes sociais na América Latina, Caio Prado Junior, Ruy Mauro Marini, Rui Facó, Sérgio Buarque de Holanda, Francisco de Oliveira (o saudoso Chico, com a metáfora do Ornitorrinco) sobre o caráter nacional e a relação centro-periferia, a subordinação da burguesia nacional ao grande capital imperialista internacional e o caráter autocrático do Estado Brasileiro e da burguesia brasileira. Daí, na concepção de autores como Florestan Fernandes e Ruy Mauro Marini a questão da ordem seria colocada no terreno da revolução brasileira ${ }^{116}$.

\section{O novo cinema de Kleber Mendonça Filho e Juliano Dorneles e a saga de Bacurau no contexto político do capitalismo neoliberal}

O impacto de Bacurau (2019) foi bastante forte nos cinemas, nos debates acadêmicos e nas redes sociais a tal ponto de um dos diretores afirmar que "Não tem filmes como Bacurau no cinema brasileiro"117. Como nos tempos do cinema novo, com Glauber Rocha, Nelson Pereira dos Santos, entre outros. O crítico Vinícius Fagundes (2019) afirma que Bacurau possui muitos elementos cinemanovistas, quase como se fosse um filme do movimento que por acaso nasceu no tempo errado. Desde o cenário sertanejo, o ritmo de início lento e final estonteante, a brasilidade absoluta e diversos outros aspectos que compõe a obra. Somado a estes fatores estéti-

${ }^{115}$ Cf. FANON, F. Los condenados de la terra. México: Fondo de Cultura Económica,1977. Ver, principalmente, a primeira parte, além do prefácio de Jean Paul Sartre. Sobre a problemática da violência, destacamos, ainda, o excelente filme, A Batalha de Argel, de Gillo Pontecorvo (1966). 
cos, de forma mais estruturalista, um dos principais pontos de convergência com o importante movimento do cinema nacional dos anos 1960 e 70 é a construção dos personagens como arquétipos. As pessoas de Bacurau não são apenas elas mesmas em si. São avatares de sua classe, sua etnia, sua jornada. A jovem que foi estudar fora representa não apenas Teresa, mas todos que fizeram o mesmo caminho. O sábio e gentil professor representa todos os professores que se sacrificam para educar pobres crianças Brasil afora mesmo contra todas as possibilidades. A doutora que faz o que pode com o pouco que tem não é apenas Domingas, ela representa todas as médicas dos precários postos de saúde que as pequeninas cidades do nosso interior mal sustentam.

Para o crítico Vinícius Fagundes (2019), enquanto nos filmes do diretor de Pulp Fiction ${ }^{118}$ a violência é puramente estética, em Bacurau, tal qual obras cinemanovistas como O Deus e o Diabo e em O Dragão da Maldade, há a virtude na violência. Ela é justificável, possui argumentos e propósitos. Em uma entrevista aqui mesmo no Brasil, Quentin Tarantino disse que seus filmes são como uma tela em branco que ele pinta com sangue $^{119}$. Já Bacurau, é uma tela pegando fogo em que o sangue apaga as chamas (FAGUNDES, 2019).

Tem a ver com a violência da fome e da miséria nordestina e no banditismo social de Antônio Silvino, passando por Jesuíno Brilhante, Corisco, Lampião, estudados por inúmeros historiadores como Eric Hobsbawm, em Rebeldes e Primitivos e Bandidos, e Rui Facó em Cangaceiros fanáticos, entre tantos outros. A composição "Candeeiro encantando", de Lenine e Paulo César Pinheiro é a expressão real dessa violência ${ }^{120}$.

De acordo com o crítico e cineasta Thiago Brandimarte Mendonça (2019) Bacurau se passa em um futuro próximo, em um povoado no interior de Pernambuco. Logo no início do filme descobrimos que o lugar viveu uma disputa recente por água, está isolado e possui um abastecimento precário. Apesar das dificuldades, seus habitantes sobrevivem em uma curiosa harmonia, numa sociedade onde bandidos, professores, putas e comerciantes parecem conservar-se unidos, dentro de uma lógica singular de equilíbrio e respeito. Essa tranquilidade é quebrada quando uma série de assassinatos acontecem próximos ao povoado, ao mesmo tempo em que o lugarejo é literalmente apagado do mapa e perde seus sinais de telefone e comunicação externa. Ilhados, precisam combater seus misteriosos inimigos. Para isso, resolvem resistir e iniciam uma guerra contra um grupo de americanos que ali se encontram para fazer "caça esportiva" com pessoas vivas, numa espécie de jogo monitorado, onde cada pessoa morta rende pontos ao assassino. À lógica facínora da classe média americana contrapõem-se então os bandoleiros da catinga e suas energias represadas de anos de lutas e sobrevivência no sertão (MENDONÇA, 2019).

\footnotetext{
${ }^{116}$ Glauber se apropria de temas sobre a realidade brasileira abordados por autores das ciências humanas do Brasil. O cineasta em seus depoimentos em artigos, cartas e entrevistas confirma a presença da sociologia e da antropologia em seus filmes: "Então o que nós do Cinema Novo propúnhamos era o seguinte; vamos tentar, dentro dos instrumentos que nós temos, quer dizer, com o conhecimento que temos no Brasil (...) era um pouco de Ciências Sociais, um pouco de literatura, um pouco de informações internacionais, ver como é que funciona esta colônia. Esta colônia, como todas da América Latina, é também um problema de índios, de pretos, de marginais, de burguesia cafajeste (apud GERBER, 1977: 99).
}

${ }^{117}$ Entrevista com o diretor Kleber Mendonça Filho A Tarde: Disponível em https://atarde.uol.com.br/muito/noticias/ 2090836-kleber-mendonca-filho-nao-tem-filmes-como-bacurau-no-cinema-brasileiro. Acesso em: 05/03/2020.

${ }^{118}$ Expressão utilizada pelo diretor norte-americano Quentin Tarantino para descrever histórias de qualidade inferior ou absurdas

${ }^{119} \mathrm{O}$ crítico Vinícius Fagundes parece estar se referindo a entrevista coletiva dada por Tarantino, quando esteve no Brasil, publicada no final de novembro de 2015, quando fez a seguinte afirmação: "Definitivamente vermelho é uma cor na minha paleta de cores. Mas a gente está falando sobre faz de conta. O sangue na vida real, é assustador, é triste, mas no cinema é falso, na verdade ele tem um gosto bem bom (...). Na ficção, eu vejo o sangue como uma tinta, e você a pinta da forma que preferir. Às vezes para ficar lindo, às vezes para ficar assustador, e outras é só engraçado mesmo". A matéria é assinada pelo jornalista e roteirista, Felipe Germano, da Superinteressante. Disponível em: https://super.abril.com.br/ cultura/uma-hora-com-tarantino/ Felipe Germanoaccess_time4 nov 2016, $19 \mathrm{~h} 03$ - Publicado em 26 nov 2015, $15 \mathrm{~h} 30$. Acesso em: 25/04/2020. A propósito dessa questão, ver: ZACHARIAS, João Cândido. (Org.) Quentin Tarantino. Rio de Janeiro, Jurubeba Produções, 2013. Obra coletiva patrocinada pelo Ministério da Cultura e Centro Cultural Banco do Brasil. 
Para Ivana Bentes (2019) há algo de profundamente perturbador em Bacurau, de Kleber Mendonça Filho e Juliano Dornelles, talvez o mais importante filme contemporâneo sobre o Brasil distópico da era Bolsonaro que se inicia em 2019. Mesmo tendo sido filmado antes das eleições de 2018 e da catástrofe política em andamento, Bacurau é um filme visionário e violento, uma ficção científica e política que não tem nada de alegórica. Ao contrário, é explicita e brutal, de uma lucidez aterradora. Sem dúvida, Bacurau é um extraordinário remix do imaginário hollywoodiano com a tradição do Cinema Novo brasileiro: a estética da fome, a estética do sonho e a pedagogia da violência de Glauber Rocha com banhos de sangue prêt-à-porter vindos dos filmes de ação e reality shows. Um filme de crítico de cinema, de cinéfilo e de um diretor que chegou ao auge da destreza narrativa (BENTES, 2019).

Bentes (2019) se indaga sobre quem são os invasores de Bacurau? "Estamos sob ataque", percebem os moradores. A chave não está apenas no grupo de gringos predadores da água e assassinos, do prefeito corrupto, mas também na dupla de brasileiros sulistas (em oposição aos moradores nordestinos) que se identifica com esses grupos ultra-conservadores. São os primeiros a serem sacrificados. Os que se acham "brancos", superiores à comunidade local, os que se identificam com seu próprio opressor. Esses são os descartáveis. A classe média de extrema-direita é a primeira a ser sacrificada pelos ultraconservadores. Ousem questionar e virem os inimigos também. Trágico e sarcástico, mas a cena dessa revelação no filme vale por todo um tratado sociológico ${ }^{121}$.

Para o sociólogo Ricardo Musse (2019), a vida social e o cotidiano de Bacurau remetem também, em certa medida, ao mundo das comunidades (outrora designadas pelo termo "favela"), onipresentes nas grandes cidades brasileiras, à dualidade entre o esforço em favor da educação, da saúde e da pacificação levado adiante por líderes comunitários, em acordo tácito ou em conflito com os indivíduos que controlam, por meio do exercício da violência, o território abandonado pelo Estado. No reino da indústria cultural, as "celebridades" associadas a Bacurau - com notoriedade equivalente à dos chefes do tráfico dos morros cariocas - são os personagens Pacote (Thomas Aquino), o matador de aluguel, e Lunga (Silvero Pereira), os fora da lei.

Musse entende que Bacurau encarna ainda a utopia de uma sociedade pós-patriarcal. O filme apresenta uma miríade de identidades individuais, comportamentos e relações afetivas alternativas às predominantes no mundo patriarcal. O esteio de experiências pouco convencionais é apresentado reflexivamente pelos próprios personagens nas cenas iniciais: o imã que configura as formas de vida do povoado é carmelita (Lia de Itamaracá), arquétipo do matriarcado.

No olhar sociológico de Musse os motociclistas são brasileiros, sulistas, funcionários do Judiciário, animados com a possibilidade de participar do esquadrão da morte. Medidos pelos olhos dos adeptos da supremacia branca, porém, tornam-se imediatamente alvos, em um ensaio do programa de assassinato em massa. O sinal da internet é bloqueado. Bacurau se torna invisível até mesmo para o satélite do Google. Não há como não se lembrar do bloqueio do espaço aéreo (supostamente realizado pela FAB). Organizados como bandoleiros, à maneira de filmes de faroeste, como tropa de ocupação, os snipers, em Bacurau, preparam a invasão, o cerco e o ataque final (MUSSE, 2019).

\footnotetext{
${ }^{120} \mathrm{Na}$ senda de Hobsbawm e Facó, é possível afirmar que o cangaço foi uma forma de banditismo social típica, um fenômeno ocorrido no Nordeste do Brasil no final do século XIX e XX e, que teve sua gênese em questões sociais e também fundiárias do nordeste brasileiro, caracterizando-se por atitudes e acontecimentos violentos de grupos ou mesmo de indivíduos isolados. Ver Lenine, (O dia em que faremos contato, CD Álbum Ariola, 1998). Lá no sertão, cabra macho não ajoelha/Nem faz parelha com quem é de traição/Puxa o facão, risca o chão, que sai centelha/ Porque tem vez que só mesmo a lei do cão/É Lampa, é Lampa, é Lampa, é Lampião/Meu candeeiro encantado/Meu candeeiro encantado/Enquanto a faca não sai toda vermelha/A cabroeira não dá sossego não/Revira bucho, estripa corno, corta orelha/Que nem já fez Virgulino, o Capitão/Já foi-se o tempo do fuzil papo amarelo/Pra se bater com poder lá do sertão/Mas lampião disse que contra o flagelo/Tem que lutar com parabelo na mão (...).
}

${ }^{121}$ BENTES, Ivana. Bacurau e a síntese do Brasil brutal. Disponível em https://revistacult.uol.com.br/home/bacurau-kleber-mendonca-filho/. Acesso em: 08/11/2019. 
Com esse movimento de campo e contracampo, o filme adiciona outras camadas de significado à metáfora do sertão. Sob a ameaça de extermínio, sitiado por um esquadrão estrangeiro, Bacurau remete - alegoricamente aos quilombos, a Canudos, às comunas anarco-comunistas, às periferias das grandes cidades brasileiras, mas também a um povo, a uma região, a um país sob a mira do imperialismo.

Diante da disparidade das forças, antevê-se o massacre, a ser devidamente acompanhado na trilha sonora por músicas como "Bichos da Noite", de Sérgio Ricardo ${ }^{122}$, "San Vicente", de Milton Nascimento e Fernando Brant - "as horas não se contavam/ e o que era negro anoiteceu / no corpo e na cidade/ um sabor de vida e morte/ um sabor de vidro e corte"123. O que se ouve, no entanto, em alto volume, é "Réquiem para Matraga", de Geraldo Vandré - "vim aqui só pra dizer/ ninguém há de me calar/ se alguém tem que morrer/ que seja pra melhorar/ tanta vida pra viver/ tanta vida a se acabar/ com tanto pra se fazer/ com tanto pra se salvar/ Você que não me entendeu/ não perde por esperar" .

As tecnologias da informação desenvolvidas no exterior, em Bacurau, são absorvidas e remodeladas em seus usos pelo filtro da cultura local. $\mathrm{O}$ avanço técnico converte-se, assim, seja na história narrada ou no arranjo interno do filme, em armas da resistência. Por meio desse quiproquó, os diretores propõem uma retomada do ideal de uma cultura nacional, um projeto inacabado que animou os momentos decisivos do cinema brasileiro (cf. Paulo Emílio Salles Gomes, Cinema: trajetória no subdesenvolvimento) ${ }^{125}$.

A ativista Helena Popineau (2019), ao comentar Bacurau, lembra que se trata de uma obra, acima de tudo, de "arte", cujo objetivo também é semear utopias e levantar um campo de discussão (e que campo!) capaz de buscar respostas para a transformação social. Em razão de sua narrativa vaga, o filme tem recebido inúmeras críticas e vem sendo apontado, em várias delas, como incentivador da violência, ou, ainda, da segregação das unidades federativas - em diferentes níveis, entre outras coisas. Não se trata disso. Bacurau versa sobre desigualdades, opressão, pertencimento e revolução ${ }^{126}$.

"Desse modo, interpretar o fato do povo de Bacurau, duramente silenciado, oprimido e excluído - metáfora nua e crua das minorias no cenário atual, reagir com as armas do inimigo; como uma forma de promoção da violência, sugere uma ingenuidade e injustiça sem precedentes. Para compreender isso: "vocês vieram ver o museu?", uma breve visita ao passado - seja a década de 1980" (POPINEAU, 2019), seja ao período mais remoto como o período do cangaço. É como se buscasse recuperar os fios da memória no sentido tão bem definido pela pesquisadora Ecléa Bosi, em sua obra Memória e sociedade. Bosi entende que a função da memória é o conhecimento do passado que se organiza, ordena o tempo, localiza cronologicamente. Assim, o passado revelado desse modo não é o antecedente do presente, é a sua fonte (BOSI, 1995).

\footnotetext{
122 Ver Sérgio Ricardo (nome artístico de João Lutfi) (A Grande Música de Sérgio Ricardo, 1967, Philips). É um dos fundadores da bossa-nova, iniciou o movimento da canção de protesto no país, passou pelo Teatro do Oprimido e o Cinema Novo, desde a década de 60. Poeta, roteirista, compositor, diretor de cinema, artista plástico, premiado dentro e fora do país. Na música, Sérgio Ricardo influenciou toda uma geração de artistas. Participou do famoso concerto do Carnegie Hall, sempre voltado para a problemática social nas raízes mais profundas do povo brasileiro, participativo politicamente contra a ditadura militar, momento em que teve suas músicas censuradas. Desta lavra, destacam-se canções que marcaram época, como "Zelão", "Calabouço", "Esse mundo é meu" e "Conversação de paz". Realizou trilhas sonoras para os filmes de Glauber Rocha, como Deus e o diabo na terra do sol e Terra em Transe, entre outros.

${ }^{123}$ Ver Milton Nascimento e Lô Borges (Álbum Clube da Esquina, 1972), Odeon.

${ }^{124}$ Ver Geraldo Vandré (Álbum de 1979), Som Maior.

125 MUSSE, Ricardo. Sobre "Bacurau”. Disponível em https://revistaforum.com.br/cultura/sobre-bacurau-por-ricardo-musse/. Acesso em: 15/12/2019.
}

126 POPINEAU, Helena. Bacurau: quando a covardia não é uma alternativa. Disponível em https://www.brasildefato. com.br/2019/09/16/artigo-or-bacurau-quando-a-covardia-nao-e-uma-alternativa. Acesso em:/10/11/2019. 
Do ponto de vista sociológico e político, Helena Popineau (2019) parece ter conseguido dar a dimensão de tudo:

\begin{abstract}
Bacurau é uma aula de resiliência, no âmbito do pouco que detém, há: uma igreja sem padres, um museu cuidadosamente protegido (e motivo de orgulho para a população), um cabaré e uma escola- com a figura de um sábio professor e uma das melhores bibliotecas da região. Quanto simbolismo! Quantas lições! Na cidade, os cidadãos "gente" formam o corpo social - sendo a coletividade o personagem principal da trama - a qual se auto-organiza para reagir, motivados pela necessidade de coesão e pelo estado de anomia que os acomete. A partir disso, na perspectiva do funcionalismo de Durkheim, o entendimento dos acontecimentos não deve perpassar pelo valor moral, mas sim pelo valor social que esse fato vai acarretar na busca do equilíbrio das partes que compõe a sociedade (POPINEAU, 2019).
\end{abstract}

"Idealmente, norteados pelos valores cristãos, tendemos a acreditar que a não violência é a melhor alternativa, ou ao menos, a mais civilizada resposta aos opressores. Contudo, ao término da oração, o despertar nos impele a abrir os olhos e encarar a política de genocídio que nos é incutida goela abaixo todos os dias. "Com quantos quilos de medo se faz uma tradição?”'127 A covardia não é uma alternativa para Bacurau, frente a um cenário de necropolítica que os assola, tampouco deveria ser para nós" (POPINEAU, 2019). Bacurau é um filme de resistência!

Já o jurista e filósofo do direito Arnaldo Sampaio Godoy (2019), ao contextualizar o filme Bacurau, procura fazer uma análise sociológica e histórica da trajetória do chamado "banditismo social" a partir de Jesuíno Brilhante (1844-1879). O cangaceiro-romântico significou a justiça onde justiça não havia e a desafronta onde desforra não acontecia. Protetor de camponeses esfomeados, de crianças maltratadas e de moças ultrajadas, Jesuíno intercalava assaltos e ataques a coronéis poderosos com intervenções espetaculares nas vilas de Belém do Brejo do Cruz. A população viu a justiça, na obra de Jesuíno; justiça não havia em nenhum outro lugar. Na mesma esteira, podemos citar os expoentes do "banditismo social" como Antônio Silvino (1875-1944), Virgulino Ferreira da Silva (1898-1938), mas popularmente conhecido como Lampião ${ }^{128}$.

Em Bacurau, como em todo sertão nordestino, há muitas carências, pobreza, falta d’água, ausência de políticas públicas, descaso dos governantes para com a população; tudo isso caracteriza a marca indelével das desigualdades sociais ${ }^{129}$. Mas há celulares, um simpático DJ, uma médica que eventualmente se embriaga (Sônia Braga, no papel de Domingas), um professor dedicado (Plínio, Wilson Rabello), um violeiro cordelista, e muitas outras personagens que decolam tanta gente sofrida. Bacurau é o Brasil (GODOY, 2019).

Ao retornar para o enterro da avó, matriarca com fumos de curandeira e conselheira, Teresa (Bárbara Colen), reencontra suas origens, e a pequena cidade ameaçada por uma horda de psicopatas. Americanos (o líder é alemão), bem armados, com drones, monitores de comunicação, e toda a extravaganza de quem vai guerrear com o inimigo letal, matam por prazer. Dois desses assassinos, após matarem um casal simplório, excitam-se e fazem amor, sob os olhares dos drones. Sadismo maior não pode haver. Bacurau é também o desumano explorador do Brasil, o turista sexual (GODOY, 2019).

\footnotetext{
${ }^{127}$ Ver Popineau (2019) e Tom Zé, Senhor Cidadão, Álbum: Silêncio de Nós Dois, EP, RGE, 1971.

128 Hobsbawm $(1970 ; 1976)$ entende o banditismo social como um tipo especial de protesto e rebelião camponesa e que constitui um fenômeno universal, que ocorre sempre que as sociedades se baseiam na agricultura (inclusive as economias pastoris), e mobiliza principalmente camponeses e trabalhadores sem terras, governados, oprimidos e explorados - por senhores, burgos, governos, advogados, ou até mesmo bancos. Pela sua complexidade, o banditismo social não tem quase organização e ideologia e não se adapta de forma alguma aos movimentos sociais modernos (HOBSBAWM, 1970: 16). Bakunin vai na mesma linha: "O bandido é sempre o herói, o defensor, o vingador do povo, o inimigo irreconciliável de qualquer Estado, regime social ou civil, o lutador de vida e de morte, contra a civilização do Estado, a aristocracia, a burocracia eo clero" (BAKUNIN Apud HOBSBAWM, 1970: 43).
} 
Arnaldo Godoy (2019) chama atenção para um detalhe importante em Bacurau: os invasores acusavam-se porque um deles havia matado uma criança. O líder do bando, seguramente um alemão educado por alguém que passou pela juventude hitlerista, categoricamente afirmava que não matava mulheres. Brincavam com a vida (alheia, de gente simples e indefesa) como quem tecla joguinhos eletrônicos. A vida não vale nada. A diversão não tem limites, porque o limite da vida é justamente a falta de limites. Bacurau é ainda o desdém do poderoso para com a significação da pessoa comum (GODOY, 2019).

Godoy parte da premissa de que a morte da anciã uniu os bacurauenses. A cena do enterro é antológica (ao som de Bichos da noite, de Sérgio Ricardo) como antológico é o violeiro (Rodger Rogério do Pessoal do Ceará) que dedilha os acordes fúnebres, fazendo eco ao carro de som e à música também fúnebre cantada pelos que choravam a perda de Dona Carmelita (Lia de Itamaracá). Domingas parece ser uma das que mais sofreu. Em uma das cenas, observando uma velha fotografia (e com cuidado pode-se reconhecer Sônia Braga dos tempos de Gabriela), Domingas revela a perda de uma pessoa querida. Bacurau é um pouco também a lembrança que a vida é feita de amizades. As personagens são retalhos de um Brasil antigo e contemporâneo, rural e ao mesmo tempo urbano. Um casal de brasileiros (com inglês fluente) auxiliava o bando assassino. Entreguismo total. Reverência fatal para com o estrangeiro explorador. No momento em que o brasileiro (Antonio Saboia) é assassinado pelo bando, pega-se seu documento, que revela que era um assessor servidor de tribunal (GODOY, 2019).

Do ponto de vista sociológico e político, uma análise do novo cinema de Kleber Mendonça Filho perpassa a trilogia: O som ao redor (2012), Aquarius (2016) e Bacurau (2019). Os três filmes expressam, de diferentes maneiras, as profundas contradições sociais da sociedade capitalista contemporânea. Tais contradições estão presentes no dia-a-dia das pessoas simples, dos pobres, excluídos sociais, e desigualdades sociais. Como bem sustenta Kleber Mendonça:

Bacurau é um filme sobre o Nordeste, mas é sobre o Brasil também, sobre pessoas. Eu gosto de gente, não sou um misantropo, gosto de gente, não todo mundo, mas gosto das pessoas que eu gosto. Então Bacurau é sobre compaixão, pessoas vivendo juntas numa comunidade e tentando se ajudar. A vida é difícil, então quando as pessoas tentam se ajudar tudo flui mais rápido. O filme tem um certo poder, é natural que algumas pessoas queiram vê-lo como militância. Eu não tenho, nem Juliano, vendido o filme dessa forma. ${ }^{130}$

Em O som ao redor é interessante notar os desníveis e a volatilidade das classes sociais no filme sempre a elite, que é para onde o diretor olhou para organizar a narrativa. A começar por seu Francisco, que de longe é o mais poderoso da rua, mas já está em condição decadente. Ele tem um engenho, e um

${ }^{129}$ Em entrevista ao portal A Tarde, Kleber Mendonça Filho enfoca a realidade nordestina a partir de uma lógica de-
sigual, combinada e contraditória e que expressa um amálgama entre tradição e modernidade: “A ideia sempre foi
mostrar um sertão moderno, porque ele já é. Vi Central do Brasil durante a montagem de Bacurau e o sertão que Wal-
ter [Salles] filmou em 1997 não é mais o sertão que existe hoje. Ainda era o sertão dos anos 1980, 1970, 1960, tinha
traços muito claros dessas décadas. Também era um sertão onde a internet ainda não tinha tido um impacto. Esses
20 anos fazem muita diferença. Hoje, o sertão faz parte do mundo de uma maneira que não fazia antes. Ele era muito
mais isolado culturalmente e socialmente. Os anos Lula também trouxeram alterações significativas. O sertão que a
gente sabia que ia filmar, e a gente sublinhou isso com direção de arte e figurino, é o sertão onde as pessoas usam
luvas, imitações de grandes marcas, porque são todas importações chinesas. Temos as bugigangas digitais, tablets,
televisões e monitores. Cada filme tem exigências. Esse exigiu que fosse feito no sertão, e nós fomos com muito prazer
e senso de descoberta. Foi inesquecível. Disponível em https://atarde.uol.com.br/muito/noticias/2090836-kleber-
-mendonca-filho-nao-tem-filmes-como-bacurau-no-cinema-brasileiro. Acesso em: 05/03/2020.

${ }^{130}$ Entrevista de Kleber Mendonça Filho a Vinícius Marques em 10/09/2019. Disponível em https://atarde.uol.com.br/muito/noticias/2090836-kleber-mendonca-filho-nao-tem-filmes-como-bacurau-no-cinema-brasileiro. Acesso em: 05/03/2020. 
engenho por si só já é algo arcaico; além disso, ele mesmo diz que já não manda tudo aquilo na rua e que muitas coisas já foram vendidas. Outro exemplo é uma mulher e filha que visitam um apartamento - que também pertence à família de Francisco (o veterano ator e diretor Waldemar Solha): elas não têm mais carro (já tiveram dois), mas ainda sim tem dinheiro suficiente para buscar um apartamento de classe média alta. Nessa mesma cena, e descendo um pouco mais: o condomínio vizinho é mais pobre, mas ainda sim o menino que entra em casa, depois de a bola ter caído para o outro lado, tem empregada. Pelo jeito de cada uma dessas pessoas em cena, percebe-se uma vontade de se colocar em posição superior, em um encadeamento de relações hierárquicas que compõe e ilustram bem a sociedade brasileira.

Como bem enfatiza o crítico Marcelo Hessel (2016), no filme Aquarius a trama segue com Clara (Sônia Braga), jornalista e crítica de música, viúva, última moradora do Aquarius, edifício antigo na valorizada orla da praia da Boa Viagem, Recife. Personificada no engenheiro Diego (Humberto Carrão), que quer derrubar o Aquarius, a especulação imobiliária é o pesadelo que assombra os dias e as solitárias noites de Clara. O diretor esboça aqui um suspense de mal-estar social parecido com o de O Som ao Redor, também próximo do terror, simbolizado no véu do arranha-céu vizinho que avança sobre a janela de Clara como um fantasma de fato. Embora não negue o confronto, porém, Aquarius está atrás de outra coisa. Por ser uma história de resistência contra o medo, não faz sentido alimentar até o fim nos próprios protagonistas de Aquarius esse sentimento que o diretor instilava tão bem por todo O Som ao Redor. Seja como for, o que fica claro é que em uma sociedade marcada por profundas contradições de classes e desigualdades sociais, na disputa pelo espaço, o chão, parafraseando Marx, não é mais chão; se transforma em capital.

O crítico Pablo Villaça (2013), ao fazer uma análise do filme $O$ som ao redor chama atenção para um fato singular: a vizinhança é comandada por uma espécie de coronel urbano chamado Francisco (Waldemar José Solha), que detém boa parte dos imóveis da rua. Outros personagens importantes são João (Gustavo Jahn), neto de Francisco, ele se incomoda com as injustiças sociais e a presença dos seguranças, e Bia (Maeve Jinkings), mãe infeliz com a rotina da casa e que enfrenta problemas com o cão de estimação do vizinho. O cenário claustrofóbico é retratado de várias formas, como o vaivém das empregadas domésticas nos apartamentos, a vigilância dos guardas noturnos, as brincadeiras de criança limitadas pelo portão do prédio, a reunião de condomínio em que se discute a demissão por justa causa do zelador (entre outras razões, porque uma moradora tem recebido a revista Veja fora do plástico). Em suma, uma classe média enjaulada e ensimesmada em dramas comezinhos. A chegada dos seguranças explicita em um estilo foucaultiano a sensação de que os moradores vivem enclausurados (VILLAÇA, 2013).

Embora a história se passe no bairro de Setúbal, na capital pernambucana, a especulação imobiliária, a urbanização inóspita e a convivência em espaços públicos e privados são temas universais. A vida numa rua de classe-média na zona sul do Recife toma um rumo inesperado após a chegada de uma milícia que oferece a paz de espírito da segurança particular. A presença desses homens traz tranquilidade para alguns, e tensão para outros, numa comunidade que parece temer muita coisa. Enquanto isso, Bia, casada e mãe de duas crianças, precisa achar uma maneira de lidar com os latidos constantes do cão de seu vizinho. Uma crônica brasileira, uma reflexão sobre história, violência e barulho.

Estabelecendo-se como um filme sobre anseios, angústias e aspirações de uma classe social que parece incerta de seu papel no mundo, O Som ao Redor também é uma narrativa sobre a perda de nossas raízes ou, no mínimo, da triste destruição de nossa história. "A casa em que tu morou vai ser derrubada", diz João à namorada, em certo instante - uma fala literal, mas que poderia perfeitamente surgir como metáfora. E, assim, quando a garota visita o lugar no qual passou parte da infância e entra no antigo quarto, sentimos a perda iminente de um aposento que, mesmo comum, assume contornos de um museu particular. Assim, quando ela percebe que a constelação de papel que colara no teto permanece lá e pede que o namorado a levante, $\mathrm{o}$ 
gesto surge como um símbolo magistral de alguém tentando tocar, pela última vez, as estrelas do céu de sua infância enquanto estas não são arrancadas pela inexorável e cruel passagem do tempo (VILLAÇA, 2013).

\section{O que mudou: o cinema brasileiro no século 21 no âmbito da nova conjuntura polítical}

Do movimento cinemanovista, até os dias atuais, muita coisa mudou. Para Glauber Rocha qualquer caminho que fosse ligado ao Brasil depois de 1964 teria forçosamente que o levar a pensar sua arte em termos mais totalizantes, ou seja, levando em conta o desenvolvimento histórico do sistema capitalista (GERBER, 1977). O cinema novo não foi um movimento que se completou; nesse sentido, ele foi uma experiência inacabada para o grupo que o gerou e para a própria sociedade brasileira. Tendo se caracterizado como movimento político através da criação de uma linguagem alternativa à linguagem do cinema tradicional (colonizado) e à do colonizador, ele nem sempre teve condições plenas de realização ${ }^{131}$. A criação de novas técnicas que geraram uma nova estética foi um processo de descobertas progressivas e de uma constante indagação, pesquisa e adaptação às transformações estruturais da sociedade brasileira. Para Glauber Rocha não se resolverão completamente os problemas desse cinema a não ser que se resolvam os conflitos reais dessa sociedade (GERBER, 1977: 28).

Na senda de Florestan Fernandes (1976; 1981), é possível afirmar o caráter do Estado autocrático-burguês cuja institucionalidade política sofre um processo acelerado de recomposição em favor do reforço e ampliação de seus elementos autoritários e fascistas e em detrimento de seus elementos democrático-representativos, configurando o que podemos caracterizar como uma "transição autoritária". Porém, como bem assinala o historiador David Maciel (2019; 2020), a dinâmica autoritária ganha novo ritmo a partir do golpe de 2016 que destituiu a presidenta Dilma Rousseff. De lá para cá, medidas como o reforço da tutela militar sobre o governo, os ataques aos direitos sociais e trabalhistas (reforma trabalhista, lei de terceirização, reforma da previdência) e à própria capacidade do Estado de executar políticas econômicas anticíclicas e garantir direitos sociais (lei do teto de gastos), a nova lei eleitoral (que escamoteia o financiamento eleitoral pelas empresas por meio das doações individuais), a manipulação política e eleitoral da Lava Jato ${ }^{132}$, o avanço mobilizatório da extrema-direita, a aplicação de uma versão ainda mais extremada do neoliberalismo, entre outras, demonstram que há um avanço acelerado das perspectivas autoritária e fascista (MACIEL, 2019). O governo de Jair Bolsonaro é expressão real dessa ofensiva da direita neofascista e reacionária que busca proteger os interesses dos grandes banqueiros e capitalistas em detrimento dos trabalhadores. ${ }^{133}$

As forças vivas do mundo do trabalho foram derrotadas pelo capital. Sem travar um só combate importante. A primeira perspectiva se apresenta no reforço do despotismo do capital sobre o trabalho, por meio da redução drástica dos controles políticos sobre a movimentação do capital e da imposição do mercado como mediador exclusivo das relações sociais. A segunda, na eliminação progressiva do espaço político da esquerda e das organizações vinculadas ao mundo do trabalho, além do uso e abuso da violência policial como mecanismo de controle social, o que implica uma repressão cada vez mais abrangente e que expressa o

131 O cinema novo ao surgir nos anos de 1960, enfrentando grandes dificuldades, cresceu em meio a uma cultura dominada por superproduções de Hollywood como um movimento entre os mais inovadores, instigantes e revolucionários da história cinematográfica mundial. Nesse sentido, surgiu como uma resposta a cinema tradicional que fazia sucesso nas bilheterias brasileiras no final da década de 1950, um cinema que se resumia a musicais, comédias e histórias épicas no estilo hollywoodiano, muitas vezes realizados com recursos de produtoras distribuidoras estrangeiras. O que fica claro, na visão de Glauber Rocha, é que cinema que estava surgindo pretendia trazer uma mensagem revolucionária (o que significa uma ruptura com passado hollywoodiano), não se preocupando apenas em ganhar dinheiro: "Nunca a gente pensou que o cinema devia uma profissão burguesa, uma arte de consumo ou uma indústria de sucesso. Era apenas um meio de comunicação mais avançado que os intelectuais de esquerda usavam porque todo mundo que fazia cinema novo queria naturalmente militância entre as práticas intelectuais, quer dizer, um grupo que deu um saldo qualitativo porque ia em direção a um meio novo" (ROCHA apud GERBER, 1977: 14). 
tratamento do conflito político e social. Neste sentido, o que restou do regime democrático-representativo e do sistema de representação política configura uma "democracia restrita", que deixou pra trás a "democracia de cooptação", criada, a partir da crise da Ditadura Militar, pela transição democrática, e que tinha o transformismo como método principal de tratamento do conflito político e social (MACIEL, 2019) ${ }^{134}$.

\section{Considerações finais}

Ao longo deste artigo, procuramos demonstrar que, inserido no interior do movimento do Cinema Novo, o cinema sociológico de Glauber Rocha se tornou uma referência estética para o próprio movimento e para o cinema brasileiro como um todo, até os dias atuais muitos filmes (como Central do Brasil de 1998 e Abril Despedaçado de Walter Salles de 2001, Cidade de Deus de Fernando Meireles de 2002 e Tropa de Elite de José Padilha realizado em 2007) e os mais recentes filmes de Kleber Mendonça Filho e Juliano Dornelles possuem um traço sociológico que se inspiram direta ou indiretamente, ou fazem alguma referência, conscientemente ou não a este estilo cinematográfico glauberiano.

Com o ascenso do movimento operário e sindical no ABC paulista, no final dos anos 1970, com as grandes greves do setor automobilístico, tivemos a produção de alguns filmes e documentários, sob a direção de importantes diretores, entre eles, Sérgio Toledo Segall e Roberto Gervitz (Braços Cruzados, Máquinas Paradas, 1979), João Batista de Andrade (O homem que virou suco, 1980), León Hirszman (Eles não usam black-tie, 1981 e ABC da Greve, 1990), e Renato Tapajós (Linha de montagem, 1982). Em 2004, foi a vez do

\footnotetext{
${ }^{132}$ O nome da operação deve-se ao uso de um posto de combustíveis (em Brasília - DF) para movimentar valores de origem ilícita, investigada na primeira fase da operação, na qual acabou sendo preso o doleiro Alberto Youssef. No Wikpedia a Operação Lava Jato é definida como um conjunto de investigações em andamento pela Polícia Federal do Brasil, que cumpriu mais de mil mandados de busca e apreensão, de prisão temporária, de prisão preventiva e de condução coercitiva, visando apurar um esquema de lavagem de dinheiro que movimentou bilhões de reais em propina. Em seu polêmico livro A elite do atraso - da escravidão à Lava Jato, o sociólogo Jessé Souza (2017) traz uma importante abordagem crítica sobre o tema. O mesmo ocorre em A classe média no espelho, de 2018, ao referir-se à Lava Jato como um conluio com os grandes aparatos midiáticos. De acordo com o autor: "O conluio entre Rede Globo, à frente da mídia venal, e Operação Lava Jato conseguiu solapar as bases normativas da vida democrática, banalizando vazamentos ilegais e agredindo criminosamente a presunção de inocência. Quando se ataca o núcleo normativo da democracia e do direito, o que resta é a Violência aberta. O êxito deste ataque pode ser medido na atual preferência de muitos, na massa da classe média e nas classes populares, pelo candidato fascista e antidemocrático" (SOUZA, 2018: 138). Para Souza (2019): "O escândalo da "Vaza Jato", provocado pelo The Intercept e pela extraordinária coragem de Glenn Greenwald, desmascarou a hipocrisia do jeito brasileiro de fazer política que já vem acontecendo há mais de cem anos. A Lava Jato não é, afinal, uma história de cinco anos que começa em 2014 com o "escândalo da Petrobras", mas sim uma história que vem desde 1930, quando Getúlio toma da "elite do atraso" o poder de Estado". Cf. Jessé Souza: Por que Moro ainda não caiu? https://midianinja.org/ editorninja/jesse-souza-por-que-moro-ainda-nao-caiu/ Acesso: 23/04/2020.
}

${ }^{133}$ Maciel $(2019 ; 2020)$ classifica o governo Bolsonaro como um governo de extrema-direita com tendências fascistizantes, unificado em torno de três eixos: o aprofundamento da escalada autocrática iniciada anteriormente e aprofundada após o golpe de 2016, a aplicação do programa neoliberal extremado e de uma pauta sócio-cultural-educacional moralista, anticomunista, fundamentalista cristã, racista, machista, misógina e homofóbica, além de anticientífica e historicamente negacionista. É um governo composto por variadas forças do campo político conservador alçadas ao poder por conta do golpe de 2016 e seus desdobramentos e da profunda crise do sistema de representação política por que passa o país: bolsonaristas/olavistas (milicianos, militares de baixa patente, policiais, carreiristas, juízes, procuradores, charlatães e ativistas do submundo digital, comerciantes e proprietários rurais); militares saudosos da Ditadura Mili$\operatorname{tar}$ ("Partido Militar"); membros do "partido do Judiciário" oriundos da operação Lava Jato, neoliberais extremados oriundos do sistema financeiro ("Partido Financeiro"), políticos da direita tradicional vinculados à grande propriedade rural, às igrejas neopentecostais e à segurança pública ("Partido fisiológico", bancada BBB). Em certa medida Bolsonaro é uma síntese de todas essas forças, radicalizando o componente autocrático e fascista presente em todas elas. (Governo Bolsonaro, ameaça fascista e luta socialista). Disponível em: https://marxismo21.org 
lançamento do documentário Peões, de Eduardo Coutinho - considerado pela crítica como um dos mais premiados diretores e considerado um dos maiores documentaristas brasileiros de todos os tempos. O documentário mergulha na recomposição da trajetória histórica dos metalúrgicos do $\mathrm{ABC}$ paulista que participaram das maiores greves do século 20. Impossível não reconhecer a influência do cinema novo nesses diretores e, sobretudo, de Glauber Rocha, seu mais importante representante.

Glauber lança crítica ao cinema industrial que não tem preocupação com os grandes problemas de seu tempo. Propõe, ao contrário, um cinema de combate, de protesto e denúncia, apresentando aspectos do drama nordestino mais próximo do que denomina - "sua verdade" fazendo desse modo, em sua obra, uma severa crítica social e política corroborando para uma nova estética cinematográfica dialética, paradoxal e com diferentes elementos.

Nas palavras do próprio Glauber Rocha, o Cinema Novo teria suas próprias peculiaridades nacionais:

Nós não queremos Eisenstein, Rossellini, Bergman, Fellini, Ford, ninguém. Nosso cinema é novo não por causa da nossa idade. O nosso cinema é novo como pode ser o de Alex Viany e o de Humberto Mauro que nos deu em Ganga Bruta nossa raiz mais forte. Nosso cinema é novo porque o homem brasileiro é novo e a problemática do Brasil é nova e nossa luz é nova e por isto novos filmes nascem diferentes dos cinemas da Europa (ROCHA, 1981: 17).

De acordo com Oliveira e Pavão (2011) Glauber fez uso do teatro da imagem como objeto de contestação, o que não exclui a mensagem política, ou seja, mesmo não fazendo um cinema puramente engajado, utiliza a imagem para chamar a atenção do espectador, tal como Brecht fazia em sua dramaturgia. Tenta a provocação do espectador, arrancá-lo da poltrona, colocando em xeque o sistema de valores do espectador, brutalizando, por meio do som, do grito, da imagem, da loucura, da miséria, da pobreza e da fome na tentativa de retirar a percepção rotineira desse espectador passivo. Tal como afirma Ismail Xavier (1996: 223): "Glauber propôs que o cinema deve negar ao espectador a posição de espectador; deve funcionar como uma provocação onírica que estimule o espectador a se desvendar enquanto homem, processo, política...”

Mesmo com dificuldade, observando a produção cinematográfica brasileira, na última década, é possível notar uma maior proliferação de filmes gestados em contextos de disputas políticas e em associação com movimentos sociais diversos, realizados seja para circulação no cinema ou na internet, nos quais se inscreve o desejo explícito de intervenção social. O cinema de arte vem surpreendendo o Brasil e o mundo no século XXI. O que se pode constatar pela gama de filmes, vídeos e documentários, produzidos nas últimas décadas. Porém, o ideal é que as exceções virem regra e que predominem produções que sejam igualmente louváveis como filmes de arte, mas que também consigam um grau tão sofisticado de comunicação com o público, a ponto de garantir tudo o que qualquer produtora ou cineasta almeja: críticas positivas, prêmios nacionais e internacionais e sucesso de bilheteria.

Nagib (2002: 13) explica que o cinema da retomada demarca um período de "renascimento" do cinema brasileiro após o Governo de Fernando Collor de Mello. O primeiro presidente eleito através do voto

\footnotetext{
${ }^{134}$ Florestan Fernandes (1976) entendia a democracia restrita como uma forma de democracia de iguais. A dominação burguesa se associa a procedimentos autocráticos, conferindo aos mecanismos representativos a existência formal, mas inoperantes socialmente. Trata-se de uma democracia para as classes dominantes, excluindo a maioria do povo, as classes despossuídas, da arena política e dos direitos de cidadania. A revolução democrática é aquela, segundo Fernandes, que "busca incorporar o povo à Nação". A democracia burguesa é uma forma política que, a despeito da hegemonia da burguesia, não elimina as classes subalternas da arena política. Para nosso autor, a implementação desse projeto significaria apenas que "a autocracia burguesa leva a uma democracia restrita típica, que se poderia designar como uma democracia de cooptação" (1976: 358-359). Ou seja: mediante um processo que Gramsci chamaria de "transformismo", o regime buscava perpetuar-se no poder por meio do cooptação de alguns segmentos moderados da oposição, mas sem abandonar - um fato sobre o qual Florestan insistia sem vacilações - a sua natureza essencialmente autocrática (TÓTORA, 1999).
} 
popular, após a Ditadura Militar de 1964/1985, teve como uma de suas primeiras iniciativas suspender todas as iniciativas governamentais que colaboravam com o desenvolvimento cultural no país, e uma delas foi extinguir a Embrafilme ${ }^{135}$, o que ocasionou uma queda na produção de filmes nacionais, praticamente zerando a produção. Com a retomada do cinema (período pós Governo Collor), que aconteceu durante a década de 90, mais especificamente, no ano de 1992, após o impeachment, as produções cinematográficas realizadas no Brasil voltaram a receber apoios e incentivos.

Eduardo Portanova Barros (2014) lembra que as produções cinematográficas hoje, de um modo geral, não se caracterizam por perseguir uma meta específica, de sentido político ou contestatório, como ocorreu nos anos 1960 com o Cinema Novo e a Estética da Fome. O cinema brasileiro já não vive uma "trajetória no subdesenvolvimento", na acepção de Paulo Emílio Sales Gomes (1996). Hoje, observando o cenário de produção de filmes, o quadro é outro. Em 2001, foi inaugurada a Ancine - Agência Nacional do Cinema e data deste período a Retomada do Cinema. Foi o período no qual o país voltou a produzir filmes, alavancados por leis de incentivo fiscal ${ }^{136}$. E também o período no qual a temática desses filmes passou a se diversificar: da crítica social (Cidade de Deus, 2002, de Fernando Meirelles) ao regionalismo (O tempo e o vento, 2013, de Jayme Monjardim), passando pelas comédias urbanas (Os normais 2 - A noite mais maluca de todas, 2009, de José Alvarenga Jr.) e o drama existencial (Estorvo, 2000, de Ruy Guerra, e O maior amor do mundo, 2006, de Cacá Diegues).

Mais recentemente, tivemos o documentário Democracia em Vertigem, de Petra Costa (2019), indicado ao Oscar e que trata diretamente da questão política brasileira, envolvendo o impeachment da presidente Dilma Rousseff, além de Dois Papas (2019), de Fernando Meireles, que vem tendo boa aceitação do público, entre tantos outros.

Em prefácio ao livro de Franthiesco Ballerini, o conceituado crítico e escritor Jean-Claude Bernardet (2012: 14), parte da premissa de que o cinema brasileiro deste século 21 pode - e precisa - passar por uma mudança de valores. Ele enfatiza que trabalhar para o público não é algo bem-visto entre os cineastas e que "o ideal seria vislumbrarmos um cinema absolutamente diversificado, que corresponda ao gosto do público e do grupo dos intelectuais, sem que seja necessário optar por um deles”. Ballerini (2012) constatou que, hoje, grande parte dos profissionais envolvidos na teoria e prática do cinema brasileiro acredita que seja necessário buscar cada vez mais um cinema que se comunique com o espectador, para a ampliação do público. Mas essas mesmas pessoas também inscrevem projetos nos editais de incentivo para falar de experiências pessoais ou temas que lhes agradem, sem levar em consideração a vontade do público.

Ballerini (2012) afirma que após uma herança composta de mais de um século de alternância de ciclos, vícios, fracassos, sucessos comerciais e artísticos e experiências foi possível observar a Pós-Retomada do cinema brasileiro. Na sua pesquisa o autor procura mostrar que, apesar dos problemas, no século 21 também houve avanços na cinematografia brasileira. A começar por sua maior diversidade: a produção nunca foi tão heterogênea. Atualmente, não há apenas uma tendência no cinema nacional - como ocorria com o Cinema Novo - mas várias, sendo produzidos desde filmes espíritas até boas e velhas comédias, além de grande gama de documentários, envolvendo questões políticas, sociais, movimentos sociais, indígenas, étnico-raciais e ecológicos. " $\mathrm{E}$ a diversificação da produção contribui para o estabelecimento de novos públicos", complementa.

${ }^{135}$ A Embrafilme ou Empresa Brasileira de Filmes S.A., fundada em 1969, foi uma empresa de economia mista estatal brasileira e distribuidora de filmes cinematográficos. Sob a direção do cineasta Roberto Farias teve uma fase bastante produtiva que durou até meados dos anos 1980.

${ }^{136}$ Para trilhar caminhos melhores, mais eficientes, no cinema brasileiro, é preciso conhecer os erros do passado, e também seus acertos. Só assim é possível evitar que o maquinário do cinema gire em falso, para que se alcance uma cinematografia bem menos dependente de recursos públicos, capaz de se pagar, de aumentar a presença de espectadores, sem deixar de surpreender em festivais e premiações internacionais por sua ousadia e diversidade (BALLERINI, 2012: 17). 
Para Ballerini o cinema de arte vem surpreendendo o Brasil e o mundo no século 21. No entanto, o ideal é que as exceções virem regra e que predominem produções que sejam igualmente louváveis como filmes de arte, mas que também consigam um grau tão sofisticado de comunicação com o público, a ponto de garantir tudo o que qualquer produtora ou cineasta almeja: críticas positivas, prêmios nacionais e internacionais e sucesso de bilheteria.

No atual contexto do capitalismo neoliberal e, por consequência, em tempo de crise econômica, política e social e de Pandemia do Novo Coronavírus (COVID-19), o cinema como arte segue tendo um papel muito importante nas culturas dos povos e, fundamentalmente, no cinema brasileiro. Diante da difícil conjuntura, o sociólogo Ricardo Antunes, em entrevista recente, com ênfase na metáfora de Bacurau, nos chama atenção para a seguinte questão; a mesma metáfora talvez possa valer para filmes, como o sul-coreano, Parasita:

Se a população estiver morrendo de doença, ela vai esperar morrer sem reagir? O filme Bacurau é uma bela metáfora do mundo. Não tinha organização na metáfora de Bacurau, é uma fotografia do destroçamento do país. No meio de uma pandemia que a população só vai se dar conta que ela pode ser brutal daqui a um tempo, os dados que vem da Itália mostram que não são só idosos os acometidos pela doença, há pessoas jovens nas UTIs dos hospitais do norte da Itália. Chega um momento em que a população, como Bacurau, diz que não dá mais. E então vão procurar ali o grupo que tem um foco de resistência que vai estruturar a organização para aniquilar o invasor estrangeiro. ${ }^{137}$

É possível concluir que o cinema brasileiro é, como fora em outras épocas com o Cinema Novo, um indispensável disseminador da cultura nacional. Importante entender como ele se sustenta e se mantém é fundamental para fazer com que esse mercado continue evoluindo e alcançando novos públicos. O cinema contribui para formar a imagem do país dentro e fora dele. Em uma produção cinematográfica os aspectos culturais são recepcionados e analisados por brasileiros e por estrangeiros. A partir desse raciocínio, entende-se que produções nacionais precisam, entre muitos pontos, conquistar o público brasileiro, fazer do cinema nacional um hábito, conforme citou Ballerini (2012). Indubitavelmente, o cinema nacional é um produto necessário para disseminar nossa cultura, além de apresentar um enorme potencial para se transformar e ser prestigiado pelos brasileiros - e pelos demais apreciadores da sétima arte, espalhados pelo mundo. Nesse sentido, o sociólogo Giovanni Alves nos brinda com uma expressão feliz, qualificando o cinema como "a sétima arte, como a arte das artes; o cinema é a única arte capaz de nos envolver de forma radical, tocar, inclusive, no núcleo humano". ${ }^{138}$

\section{Referências}

ANTUNES, Ricardo. Entrevista a Helena Dias, 25/03/2020, Marco Zero. Disponível em: http://marcozero.org/chega-uma-hora-que-a-saida-e-ao-modo-do-filme-bacurauentende-adverte-ricardo-antunes/. Acesso em: 27 mar. 2020.

BALLERINI, Franthiesco. 2012. Cinema brasileiro no século 21: reflexões de cineastas, produtores, distribuidores, exibidores, artistas, críticos e legisladores sobre os rumos da cinematografia nacional. São Paulo: Summus Editorial.

BARROS, Eduardo Portanova. 2014. "O cinema brasileiro na pós-retomada: entre o imaginário autoral e a realidade figurativa”. Esferas, n $^{\circ}$ 4: jan./jun. pp. 185-191.

\footnotetext{
${ }^{137}$ Cf. Entrevista de Ricardo Antunes a Helena Dias, Marco Zero, 25/03/2020. Disponível em:http://marcozero.org/chega-uma-hora-que-a-saida-e-ao-modo-do-filme-bacurau-entende-adverte-ricardo-antunes/. Acesso em: 27/03/2020.

${ }^{138}$ Cf. Entrevista ao Núcleo Piratininga de Comunicação. Disponível em: http://nucleopiratininga.org.br/giovanni-alves-o-cinema-e-a-unica-arte-capaz-de-nos-envolver-de-forma-radical-tocar-inclusive-no-nucleo-humano/. Acesso em: 15/03/2020.
} 
BENJAMIN, Walter. 1985. Magia e técnica, arte e política. São Paulo: Brasiliense.

BENTES, Ivana. Bacurau e a sintese do Brasil brutal. Disponível em: https://revistacult.uol.com.br/home/ bacurau-kleber-mendonca-filho/. Acesso em: 27 abr. 2020.

BERNARDET, Jean-Claude e RAMOS, Alcides Freire. 1994. Cinema e história do Brasil. São Paulo: Contexto. Brasil em tempo de cinema.1978. Rio de Janeiro: Ed. Paz e Terra. O que é cinema. 2006. São Paulo: Brasiliense.

. Cinema brasileiro: propostas para uma história. 2009. São Paulo: Companhia das Letras.

BOSI, Ecléa.1995. Memória e sociedade. São Paulo: Companhia das Letras.

CASTELO, Sander Cruz. 2010. A ética revolucionária: utopia e desgraça em TERRA EM TRANSE (1967). Fortaleza-CE: Tese de doutorado em Sociologia, Universidade Federal do Ceará.

COSTA, Nicoly de Souza; MOTTA, Rafael Vieira; RICCO, Adriana Sartório. A linguagem do cinema novo: Glauber Rocha e seus mitos. Disponível em: < http://webjornal.fesv.br/artigos/arquivos/alunos/rafael.pdf>. Acesso em: 20 nov. 2019.

FACÓ, Rui. 1976. Cangaceiros e fanáticos. Rio de Janeiro: Civilização Brasileira.

FAGUNDES, Vinícius. Bacurau, o novo Cinema Novo e o Marxismo. Disponível em: https://medium.com/@ Vinicius_Fagundes/bacural-o-novo-cinema-novo-e-o-marxismo-731675e8fed. Acesso em: 10 mar. 2020.

FANON, Frantz. 1977. Los condenados de la terra. México: Fundo de Cultura Económica. 2008. Pele negra, máscaras brancas. Salvador: EDUFBA.

FERNANDES, Florestan. 1981. Capitalismo dependente e as classes sociais na América Latina. Rio de Janeiro: Zahar. .1976. A revolução burguesa no Brasil. Rio de Janeiro: Zahar.

GARDIES, René. 1977. Glauber Rocha: política, mito e linguagem. In: GOMES, P. E. S. et al. Glauber Rocha. Rio de Janeiro: Paz e Terra. p. 41-88.

GERBER, Raquel. 1977. Glauber Rocha e a experiência inacabada do Cinema Novo. In: GOMES, P. E. S. et al. Glauber Rocha. Rio de Janeiro: Paz e Terra. p.10-40.

GERBER, Raquel. 1982. O mito da civilização Atlântica - Glauber Rocha, Cinema, Política e a Estética do Inconsciente. Petrópolis: Vozes.

GODOY, Arnaldo Sampaio de Moraes. 2013. Sobre o filme Bacurau, de Kleber Mendonça Filho e Juliano Dornelles. Disponível em: https://www.conjur.com.br/2019-dez-13/arnaldo-godoy-bacurau-kleber-mendonca-filho-juliano-dornelles. Acesso em: 15 dez. 2019.

GOMES, Paulo Emílio Salles. 1980. Cinema: trajetória no subdesenvolvimento. Rio de Janeiro: Paz e Terra.

GUIMARÃES, Antonio Sérgio A. 2008. "A recepção de Fanon no Brasil e a identidade negra”. Novos Estudos, n. 81: 99-114. 
HESSEL, Marcelo. Aquarius/Crítica/Do que são feitas as memórias. Disponívelhttps://www.omelete.com.br/ filmes/criticas/aquarius-critica. Acesso em: 15 dez. 2019.

HOBSBAWM, Eric. 1970. Rebeldes e primitivos. Rio de Janeiro.

1976. Bandidos. Rio de Janeiro: Forense.

SILVA JUNIOR, Humberto Alves. 2006. Glauber Rocha: arte, política e cultura. Trabalho apresentado no II ENECULT - Encontro de Estudos Multidisciplinares em Cultura, realizado de 03 a 05 de maio de 2006, na Faculdade de Comunicação/UFBa, Salvador-Bahia-Brasil.

SILVA JUNIOR, Humberto Alves. 2017. Da violência: o pensamento de Frantz Fanon e o cinema social de Glauber Rocha. XVIII Congresso Brasileiro de Sociologia 26 a 29 de julho de 2017, Brasília (DF) GT17 - Sociologia da Arte.

JUNIOR, Nelson Silva. Cinema Novo e Glauber Rocha: a identidade do cinema nacional. Disponível em: http:// www.cih.uem.br/anais/2013/trabalhos/171_trabalho.pdf. Acesso em: 20 fev. 2020.

KOLAKOWSKI, Leszek. 1985. O espírito revolucionário. Marxismo - utopia e antiutopia. Brasília: Ed. da UNB.

LEITE, Sidney Ferreira. 2005. Cinema brasileiro: das origens à retomada. São Paulo: Editora Fundação Perseu Abramo.

MACIEL, Davi. Aliança Brasil. Análise de Conjuntura. Escola de Formação Soc. Disponível em: http://bit.ly/c_davidmaciel, http://escoladeformacaosocialista.blogspot.com/p/analises-de-conjuntura.html. Acesso em: 5 fev. 2020.

MACIEL, Davi. Análise de Conjuntura. Escola de Formação Socialista, 22 de março de 2020. Disponível em: http://escoladeformacaosocialista.blogspot.com/p/analises-de-conjuntura.html. Acesso em. 22 mar. 2020.

MENDONÇA, Thiago B. 'Bacurau' e a nova onda do cinema brasileiro. Disponível em: https://epoca.globo.com/ thiago-b-mendonca/cinema-bacurau-a-nova-onda-do-cinema-brasileiro-23917057. Acesso em: 5 mar. 2020.

MUSSE, Ricardo. Sobre "Bacurau". Disponível em: https://revistaforum.com.br/cultura/sobre-bacurau-por-ricardo-musse/. Acesso em: 15 dez. 2019.

NAGIB, Lucia. 2002. O cinema da retomada: depoimentos de 90 cineastas dos anos 90 . São Paulo, Editora 34 Ltda.

OLIVEIRA, William V. de; PAVÃO, Eduardo Nunes A. 2011. Arte e política no cinema de Glauber Rocha: uma análise do filme Deus e o Diabo na Terra do Sol. Tempos Históricos, v. 15: 191-202. Disponível em: http://e-revista.unioeste.br/index.php/temposhistoricos/article/view/5704. Acesso em: 17 fev. 2020.

POPINEAU, Helena. Bacurau: quando a covardia não é uma alternativa. Disponível em: https://www.brasildefato.com.br/2019/09/16/artigo-or-bacurau-quando-a-covardia-nao-e-uma-alternativa/. Acesso em: 10 nov. 2019.

ROCHA, Glauber. 1980. A revolução do cinema Novo. Rio de Janeiro: Alhambra/Embrafilme.

ROCHA, Glauber. 1965. "Uma estética da fome”. Revista Civilização Brasileira, n. 3: 165-170.

SILVA, Alessandra Schmite da. 2010. A arte-política de Glauber Rocha: O cinema como instrumento de conscientização social. XIV Encontro Regional da ANPUH - Rio de Janeiro, 19 a 23 de julho de 2010.

VILLAÇA, Pablo. O som ao redor. Disponível em: http://cinemaemcena.cartacapital.com.br/critica/filme/5862/o-som-ao-redor. Acesso em: 30 jan. 2020. 
TÓTORA, Silvana. 1999. “A questão democrática em Florestan Fernandes”. Lua Nova, n. 48: 109-126.

XAVIER, Ismail. 2001. O Cinema Brasileiro Moderno. São Paulo: Paz e Terra.

XAVIER, Ismail. 1996. O Cinema no Século. Rio de Janeiro: Imago.

\section{Sites consultados}

https://medium.com/@Vinicius_Fagundes/bacural-o-novo-cinema-novo-e-o-marxismo 731675e8fed.

https://epoca.globo.com/thiago-b-mendonca/cinema-bacurau-a-nova-onda-do-cinema brasileiro-23917057.

https://revistacult.uol.com.br/home/bacurau-kleber-mendonca-filho/.

https://revistaforum.com.br/cultura/sobre-bacurau-por-ricardo-musse/.

https://www.brasildefato.com.br/2019/09/16/artigo-or-bacurau-quando-a-covardia-nao-e-uma-alternativa/ https://www.conjur.com.br/2019-dez-13/arnaldo-godoy-bacurau-kleber-mendonca-filho-juliano-dornelles https://www.omelete.com.br/filmes/criticas/aquarius-critica.

http://cinemaemcena.cartacapital.com.br/critica/filme/5862/o-som-ao-redor

Recebido em 26/04/2020

Aceito em 27/04/2020 
